\title{
Prevalensi Nyeri Tenggorok Pascaoperasi dengan Pemberian Lubrikasi VCO pada Pemasangan LMA
}

\author{
Rahmadhya Khairina Rianti ${ }^{1}$, Dedy Kurnia ${ }^{2}$, Afdal $^{3}$ \\ ${ }^{1}$ Fakultas Kedokteran Universitas Andalas, Padang \\ ${ }^{2}$ Bagian Anestesi Fakultas Kedokteran Universitas Andalas/RSUP dr. M. DJamil Padang \\ ${ }^{3}$ Bagian Anatomi Fakultas Kedokteran Universitas Andalas
}

\begin{abstract}
A B S T R A C T
Latar Belakang. Nyeri tenggorok pascaoperasi adalah komplikasi yang sering terjadi setelah anastesia umum. Hal ini dapat mempengaruhi kepuasan pasien dan mempengaruhi aktivitas pasien. Penggunaan alat bantu napas supraglotik menjadi alternatif selain intubasi trakea yang berpotensi dalam mencegah nyeri tenggorok pascaoperasi. Beberapa bahan telah digunakan sebagai pelumas untuk mengurangi kejadian nyeri tenggorok pascaoperasi dengan efikasi yang bervariasi.

Objektif. Menentukan prevalensi nyeri tenggorok pascaoperasi pada pasien dengan pemberian Virgin Coconut Oil (VCO) sebagai pelumas pada pada pemasangan Laryngeal Mask Airway (LMA) yang menjalani anestesi umum untuk operasi elektif.
\end{abstract}

Metode. Penelitian ini adalah penelitian deskriptif observasional, dilakukan pada bulan Desember 2019 hingga Juni 2020 di Instalasi Bedah RSUP dr. M. Djamil Padang dan Rumah Sakit Universitas Andalas. Empat puluh dua subjek diikutsertakan dalam penelitian ini yang diambil dengan menggunakan teknik consecutive sampling.

Hasil. Nyeri tenggorok pascaoperasi dinilai pada jam ke-0, pada jam ke-2, dan jam ke-24 pascaoperasi. Nyeri tenggorok terjadi pada $47,6 \%$ subjek pada jam ke-0 pasca operasi. Setelah jam ke-2, sebanyak $23,8 \%$ subjek mengalami nyeri tenggorok, dan setelah jam ke-24 jam hanya 9,5\% subjek mengalami nyeri tenggorok. Setelah jam ke-24 pascaoperasi nyeri yang masih dialami subjek merupakan nyeri dengan derajat ringan.

Kesimpulan. Lubrikasi VCO pada LMA dapat mengurangi prevalensi nyeri tenggorok pascaoperasi.

Kata kunci: Laryngeal Mask Airway, nyeri tenggorok pascaoperasi, Virgin Coconut Oil

Background. Postoperative sore throat (POST) is a common complication after general anesthesia. It affects patient satisfaction and can affect activity after discharge. The supraglottic airway device (SAD) offers an alternative to traditional tracheal intubation with potential benefit in preventing sore throat. Numerous agents have been used as a lubricant to reduce the incidence of POST with variable efficacy. The purpose of this study is to determine the prevalence of postoperative sore throat in patients with Virgin Coconut Oil (VCO) as a lubricant for Laryngeal Mask Airway (LMA) insertion in patients undergoing general anesthesia for elective surgery.
Objective. Determine the prevalence of postoperative sore throat in patients by giving Virgin Coconut Oil (VCO) as a lubricant for the Laryngeal Mask Airway (LMA) installation under general anesthesia for elective surgery.

Method. This is an observational descriptive study, was conducted from December 2019 until June 2020 at Surgical Installation RSUP dr. M. Djamil Padang and Andalas University Hospital. Forty-two subjects were recruited to this study taken by using a consecutive sampling technique.

Result. Patients evaluated about sore throat immediately, 2 hours, and 24 hours postoperative period. POST was observed in $47,6 \%$ of the patients in the immediate post-operative period. After 2 hours 23,8\% of patients had sore-throat, and after 24 hours 9,5\% of patients had sore-throat. Among patients who had a sore throat after 24 hours, the intensity was mild.

Conclusion. We conclude that the lubricating cuff of LMA with VCO can reduce the prevalence of POST.

Keywords: Laryngeal Mask Airway, sore throat, Virgin Coconut Oil

\section{Apa yang sudah diketahui tentang topik ini?}

Nyeri tenggorok pascaoperasi pada pemasangan LMA lebih rendah dibandingkan dengan ETT.

\section{Apa yang ditambahkan pada studi ini?}

dapat dikurangi dengan memberikan lubrikasi pada LMA Pemberian VCO sebagai lubrikan pada LMA dapat menurunkan prevalensi nyeri tenggorok pascaoperasi sampai $9,5 \%$.

\section{CORRESPONDING AUTHOR}

Name: Rahmadhya Khairina Rianti

Phone: 082231763598

E-mail: rrkhairina@gmail.com

\section{ARTICLE INFORMATION}

Received: September $23^{r d}$, 2020

Revised: October $15^{\text {th }}, 2020$

Available online: October $31^{\text {st }}$, 2020 


\section{Pendahuluan}

Nyeri tenggorok pascaoperasi atau postoperative sore throat (POST) merupakan komplikasi yang sering terjadi pada pasien yang menjalani operasi dengan anestesi umum. Kekerapan nyeri tenggorok pascaoperasi lebih sering terjadi pada anestesi umum dengan pemasangan pipa endotrakea dibandingkan dengan penggunaan Laryngeal Mask Airway (LMA).1,2 Angka kekerapan nyeri tenggorok pascaoperasi pada pasien yang menjalani anestesi umum dengan intubasi trakea yaitu antara 21\% sampai 65\%, sedangkan kekerapan nyeri tenggorok pascaoperasi pada insersi LMA lebih rendah yaitu antara 5,8\% sampai 34\%,3,4 beberapa penelitian menemukan angka kekerapan yang masih tinggi sampai $49 \% .1,2$

Pengukuran intensitas nyeri sangat subjektif dan individual. Visual Analogue Scale (VAS) merupakan alat pengukuran intensitas nyeri yang disajikan dalam bentuk garis horisontal dan dianggap paling efisien yang telah digunakan dalam penelitian klinis. Dalam perkembangannya VAS menyerupai Numerical Rating Scale (NRS) yang cara penyajiannya diberikan angka 0-10 yang masing-masing nomor dapat menunjukkan intensitas nyeri yang dirasakan oleh pasien. Dalam beberapa penelitian yang dilakukan untuk menilai intensitas nyeri pascaoperasi, skala yang digunakan adalah kombinasi antara VAS dan NRS karena metode ini paling sensitif dan dapat menggambarkan intensitas nyeri. ${ }^{5}$

Teknik anestesi umum dengan menggunakan LMA telah menjadi pilihan sebagai alat untuk manajemen jalan napas baik dalam prosedur operasi elektif dan kondisi darurat untuk jalan napas yang sulit. Laryngeal Mask Airway merupakan alternatif terhadap sungkup muka atau intubasi trakea untuk pemeliharaan jalan nafas selama anestesi. Laryngeal Mask Airway merupakan alat penatalaksanaan jalan nafas supraglotis yang dirancang dengan seal mengelilingi pintu masuk laring. Berbagai penelitian terhadap angka kejadian nyeri tenggorok pascaoperasi setelah penggunaan LMA mendapatkan hasil yang sangat bervariasi, tergantung dari jenis lubrikan yang digunakan, tingkat tekanan yang diberikan pada kaf LMA, dan tingkat keberhasilan pemasangan LMA. Berbagai lubrikan telah digunakan untuk mengurangi insidens nyeri tenggorok pascaoperasi setelah pemasangan LMA dengan keberhasilan yang berbeda-beda. ${ }^{6}$

Patil et al., pada tahun 2019 di India melakukan penelitian terhadap 60 pasien dengan membandingkan angka kekerapan nyeri tenggorok pascaoperasi dengan menggunakan LMA yang dilubrikasi dengan betametason gel $0,05 \%$ dibandingkan dengan lidokain gel $2 \%$. Pada kelompok pasien yang mendapatkan betametason gel $0,05 \%$ tidak didapatkan nyeri tenggorok pascaoperasi, sedangkan pada kelompok pasien yang mendapatkan lidokain gel $2 \%$ terdapat $33 \%$ pasien yang mengalami nyeri tenggorok pascaoperasi derajat ringan dan $10 \%$ mengalami nyeri tenggorok pascaoperasi derajat sedang. Penelitian ini mendapatkan hasil bahwa pemberian betametason gel $0,05 \%$ dapat menurunkan kejadian nyeri tenggorok pascaoperasi. ${ }^{6}$ De Villager et al. di Belgia pada tahun 1996 melakukan penelitian dengan menggunakan xilokain spray $10 \%$, silko spray, endos gel, dan air sebagai lubrikan pada saat pemasangan LMA klasik. Penelitian ini mendapatkan hasil tidak terdapat perbedaan yang bermakna secara statistik terhadap penurunan insidens kekerapan kejadian nyeri tenggorok pascaoperasi dengan menggunakan obat-obatan tersebut. ${ }^{7}$ Keller et al. di Austria pada tahun 1996 melakukan penelitian dengan membandingkan penggunaan $\mathrm{NaCl}$ dan lignocaine gel $2 \%$ sebagai lubrikan pada saat pemasangan LMA klasik. Penelitian ini mendapatkan insiden kekerapan kejadian nyeri tenggorok pascaoperasi yang hampir sama antara kedua kelompok. ${ }^{8}$ Tinjauan sistematis yang dilakukan oleh Tanaka et al. pada tahun 2010 menyimpulkan bahwa pemberian lidokain topikal dan sistemik dapat menurunkan kejadian nyeri tenggorok pascaoperasi. ${ }^{9}$ Efikasi tablet strepsil, flutikason propionat inhalasi, benzidamin hidroklorida spray, dan topikal steroid juga sudah pernah diteliti, ${ }^{6}$ namun, belum ada obat tunggal yang telah diterima secara luas untuk mengurangi kejadian nyeri tenggorok pascaoperasi. 4,6

Virgin Coconut Oil (VCO) merupakan minyak kelapa murni produk asli olahan Indonesia yang mulai banyak digunakan untuk berbagai hal. Virgin Coconut Oil terbuat dari daging kelapa segar yang diolah dalam suhu rendah atau tanpa melalui pemanasan, sehingga kandungan yang penting dalam minyak tetap dapat dipertahankan. 
Minyak tersebut mempunyai kandungan asam laurat sebagai asam lemak jenuh dengan kadar yang sangat tinggi sekitar 50,5\%. Asam lemak ini mudah diserap oleh tubuh karena ukuran molekulnya tidak terlalu besar seperti asam lemak rantai panjang. Beberapa penelitian menyimpulkan bahwa kandungan asam lemak dalam VCO berpotensi untuk dikembangkan sebagai analgetik, antipiretik, antiinflamasi ${ }^{10-13}$, sebagai obat untuk menyembuhkan luka bakar, antimikroba, ${ }^{14}$ sebagai pelembab untuk melindungi kulit dan mencegah kulit kering,15 sebagai pelumas untuk mengurangi efek gesekan dan geseran. ${ }^{16}$

Manfaat VCO sebagai analgetik dan antiinflamasi mungkin dapat digunakan untuk mengurangi nyeri tenggorok pascaoperasi akibat pemasangan LMA. Bahan baku pembuatan VCO juga banyak tersedia di Indonesia sehingga mudah dijumpai di pasaran dengan harga yang terjangkau. Selain itu sampai saat ini belum ada lubrikan yang efektif untuk mengurangi nyeri tenggorok pascaoperasi akibat insersi LMA. Belum ada penelitian yang menggunakan VCO sebagai lubrikan pada saat insersi LMA.

Berdasarkan uraian di atas, peneliti ingin melakukan penelitian untuk melihat prevalensi nyeri tenggorok pascaoperasi pada pemasangan LMA yang dilubrikasi dengan VCO. Dengan efek samping yang minimal atau bahkan tanpa efek samping diharapkan VCO menjadi pilihan lubrikan efektif pada nyeri tenggorok pascaoperasi. Penilaian nyeri tenggorok pascaoperasi pada penelitian ini dilakukan pada jam ke-0 (dinyatakan saat pasien sudah bangun setelah selesai operasi yang ditandai dengan nilai Aldrette 9-10), jam ke 2 (dihitung 2 jam setelah jam ke-0) dan jam ke 24 (dihitung 24 jam setelah jam ke-0).

\section{Metode}

Penelitian ini merupakan penelitian observasional deskriptif, untuk melihat prevalensi nyeri tenggorok pascaoperasi pada pasien yang menjalani operasi dengan narkose umum menggunakan LMA yang dilubrikasi dengan VCO. Populasi penelitian ini adalah pasien dewasa yang akan menjalani operasi dengan anestesi umum yang menggunakan LMA untuk manajemen jalan nafas di RSUP dr. M. Djamil Padang dan RS Universitas Andalas pada bulan Desember 2019 sampai bulan Juni 2020. Sampel penelitian adalah subjek yang termasuk kriteria inklusi dan tidak memiliki kriteria eksklusi. Pengambilan sampel dilakukan dengan menggunakan metode consecutive sampling sampai jumlah sampel yang diperlukan terpenuhi sebanyak 42 subjek. Setelah seluruh data terkumpul dan diseleksi, data diverifikasi dan diolah menggunakan program SPSS for windows version 23.0. Penelitian ini telah lulus kaji etik dengan nomor surat: 83/KEPK/2020 dan 104/KEP/FK/2020.

\section{Hasil}

\section{Karakteristik Subjek Penelitian}

Karakteristik subjek penelitian meliputi usia, jenis kelamin, tinggi badan, berat badan, IMT, status fisik ASA, Mallampati, dan lama operasi.

Tabel 1. Karakteristik Subjek Penelitian ( $n=42)$

\begin{tabular}{lccc}
\hline Karakteristik & n (\%) & $\begin{array}{c}\text { Rata-rata } \\
\text { (simpang } \\
\text { baku) }\end{array}$ & $\begin{array}{c}\text { Median } \\
\text { (min- } \\
\text { max })\end{array}$ \\
\hline Usia (tahun) & & & $\begin{array}{c}39 \\
\text { Jaku }\end{array}$ \\
$\begin{array}{l}\text { Jenis kelamin } \\
\text { Laki-laki }\end{array}$ & $17(40.5)$ & & \\
$\quad$ Perempuan & $25(59.5)$ & & 161.5 \\
Tinggi Badan & & & \\
(cm) & & $59.07(6.95)$ & \\
Berat Badan (kg) & & $22.45(1.92)$ & \\
IMT (kg/m ${ }^{2}$ ) & & & \\
Status fisik ASA & & & \\
$\quad$ ASA I & $20(47.6)$ & & \\
$\quad$ ASA II & $22(52.4)$ & & 121.5 \\
Mallampati & & & $(58-180)$ \\
$\quad$ Kelas I & $25(59.5)$ & & \\
$\quad$ Kelas II & $17(40.5)$ & & \\
Lama operasi & & & \\
(menit) & & & \\
\hline
\end{tabular}

Nilai tengah usia subjek adalah 39 tahun (dengan rentang usia 18-72 tahun). Jumlah subjek didominasi oleh perempuan, lebih banyak 8 subjek dibanding laki-laki. Nilai ASA berimbang antara kedua kelompok dan skor Mallampati lebih banyak dengan nilai satu. Nilai tengah lama operasi 121,5 menit dengan rentang nilai antara 58 - 180 menit.

\section{Kekerapan Nyeri Tenggorok Pascaoperasi Setelah Pemberian Lubrikasi VCO pada LMA \\ Kekerapan nyeri tenggorok pascaoperasi dinilai pada jam ke-0, jam ke-2 dan jam ke-24 dengan hasil terlihat pada Tabel 2 .}


Tabel 2. Kekerapan Nyeri Tenggorok Pascaoperasi Setelah Pemberian Lubrikasi VCO Pada LMA

\begin{tabular}{lcc}
\hline \multirow{2}{*}{ Waktu } & \multicolumn{2}{c}{ Nyeri Tenggorok } \\
\cline { 2 - 3 } & Ya n (\%) & Tidak n (\%) \\
\hline Jam ke-0 & $20(47,6)$ & $22(52,4)$ \\
Jam ke-2 & $10(23,8)$ & $3276,2)$ \\
Jam ke-24 & $4(9,5)$ & $38(90,5)$ \\
\hline
\end{tabular}

Pada tabel 2 terlihat bahwa pada jam ke- 0 pascaoperasi $52,4 \% \quad(n=22) \quad$ subjek tidak merasakan nyeri tenggorok pascaoperasi setelah tindakan pemasangan LMA yang dilubrikasi dengan VCO. Sebanyak 47,6\% (n=20) subjek merasakan nyeri tenggorok pada jam ke-0 pascaoperasi. Pada jam ke-2 sebanyak 23,8\% $(\mathrm{n}=10)$ subjek masih mengalami nyeri tenggorok, sedangkan pada jam ke-24 hanya 9,5\% $(n=4)$ subjek yang masih mengalami nyeri tenggorok, dan terjadi penurunan nyeri tenggorok sebesar $38,1 \%$ dibanding dengan jam ke-0 pascaoperasi.

3. Proporsi Nilai VAS pada Subjek yang Mengalami Nyeri Tenggorok Pascaoperasi Setelah Pemberian Lubrikasi VCO pada LMA

Intensitas nyeri tenggorok pascaoperasi pada pasien setelah pemasangan LMA yang dilubrikasi VCO dinilai dengan VAS, yang hasilnya dapat dilihat pada Tabel 3 di bawah ini.

Tabel 3. Proporsi Nilai VAS Pada Pasien Yang Mengalami Nyeri Tenggorok Pascaoperasi Setelah Pemberian Lubrikasi VCO Pada LMA

\begin{tabular}{lllll}
\hline \multicolumn{1}{c}{ Waktu } & \multirow{2}{*}{$\mathbf{N}$} & \multicolumn{3}{c}{ VAS n (\%) } \\
\cline { 3 - 5 } & & \multicolumn{1}{c}{$\mathbf{1}$} & \multicolumn{1}{c}{$\mathbf{2}$} & \multicolumn{1}{c}{$\mathbf{3}$} \\
\hline Jam ke -0 & 20 & $7(35.0)$ & $11(55.0)$ & $2(10.0)$ \\
Jam ke-2 & 10 & $8(80.0)$ & $2(20.0)$ & 0 \\
Jam ke-24 & 4 & $4(100)$ & 0 & 0 \\
\hline
\end{tabular}

Pada Tabel 3. dapat dilihat sebaran nilai VAS pasien yang mengalami nyeri tenggorok pascaoperasi setelah pemasangan LMA yang dilubrikasi VCO. Pada jam ke-0 sebanyak 47,6\% $(n=20)$ subjek penelitian merasakan nyeri dengan nilai VAS antara $1-3$ dan didominasi VAS 2 sebanyak 55\% ( $\mathrm{n}=11)$. Pada jam ke-2 pasien yang mengalami nyeri tenggorok berkurang menjadi 10 subjek dengan nilai VAS antara $1-2$ dan didominasi VAS 1 sebanyak 80\% (n=8). Pada jam ke-24 hanya 4 subjek yang mengalami nyeri tenggorok dengan nilai VAS 1.

\section{Derajat Nyeri Tenggorok Pascaoperasi Berdasarkan NRS Setelah Pemberian Lubrikasi VCO pada LMA}

Intensitas nyeri tenggorok pascaoperasi pada pasien setelah pemasangan LMA yang dilubrikasi VCO dinilai juga dengan NRS, yang hasilnya dapat dilihat pada Tabel 4. di bawah ini.

Tabel 4. Derajat Nyeri Tenggorok Pascaoperasi Berdasarkan NRS Setelah Pemberian Lubrikasi VCO Pada LMA

\begin{tabular}{ccccc}
\hline Waktu & \multicolumn{4}{c}{ Nyeri Tenggorok } \\
\cline { 2 - 5 } & $\mathbf{0}$ & $\mathbf{1}$ & $\mathbf{2}$ & $\mathbf{3}$ \\
\hline Jam ke-0 & $20(47,6)$ & $22(52,4)$ & 0 & 0 \\
Jam ke-2 & $10(23,8)$ & $3276,2)$ & 0 & 0 \\
Jam ke-24 & $4(9,5)$ & $38(90,5)$ & 0 & 0 \\
\hline
\end{tabular}

Pada tabel 4.4 dapat dilihat bahwa derajat nyeri berdasarkan NRS pada jam ke-0 sebanyak $47,6 \%(n=20)$ subjek mengalami nyeri tenggorok dengan NRS Pada jam ke-2 nyeri tenggorok dialami oleh $23,8 \%(n=10)$ subjek dengan nilai NRS 1. Sedangkan pada jam ke-24 hanya 9,5\% $(\mathrm{n}=4)$ subjek yang mengalami nyeri tenggorok dengan nilai NRS 1 . Pada penelitian ini terlihat bahwa setelah jam ke24 nyeri tenggorok yang dialami pasien adalah derajat ringan

\section{Pembahasan}

Kejadian nyeri tenggorokan pascaoperasi merupakan komplikasi anestesi kategori ringan, namun dapat memberikan kontribusi terhadap angka morbiditas pascaoperasi dan tingkat kepuasan pasien, serta merupakan salah satu kejadian efek samping yang sering dikeluhkan pasien pada periode pascaoperasi. Penggunaan LMA untuk mempertahankan jalan napas selama operasi yang di tempatkan pada superior laring menyebabkan trauma yang lebih sedikit sehingga inflamasi dan edema yang ditimbulkan akibat penggunaannya juga lebih ringan. Prevalensi nyeri tenggorok pascaoperasi yang diakibatkannya juga lebih rendah dibandingkan kalau menggunakan ETT. Nyeri tenggorok pascaoperasi yang terjadi akibat insersi LMA biasanya berhubungan dengan teknik dan metode insersi LMA, pengalaman dokter anestesi saat insersi LMA, jenis dan ukuran LMA yang digunakan, serta tekanan kaf LMA.1,2,4,17-19

Penelitian ini melibatkan 42 subjek dengan karakteristik yang ditunjukkan pada Tabel 1. Usia subjek penelitian bervariasi mulai dari 18 tahun - 
72 tahun dengan nilai tengah 39 tahun, jumlah subjek perempuan $(\mathrm{n}=25)$ lebih banyak dari lakilaki ( $\mathrm{n}=17)$. Rata-rata IMT adalah $22,45 \mathrm{~kg} / \mathrm{m}^{2}$ dan dari semua subjek tidak ada yang masuk dalam kategori obesitas. Obesitas merupakan kriteria eksklusi dari penelitian ini. Kondisi status fisik subjek praanestesi yang diklasifikasikan dalam ASA berimbang antara ASA I dan ASA II (20 subjek vs 22 subjek). Skor Mallampati yang digunakan untuk memprediksi kemudahan pada saat insersi LMA juga berimbang antara Mallampati I dan Mallampati II (25 subjek vs 17 subjek). Pada penelitian ini lama operasi tersingkat adalah 58 menit dan yang terlama 180 menit. Operasi kurang dari satu jam hanya terdapat pada satu subjek, dan operasi di atas 2 jam terdapat pada 25 subjek.

Pada Tabel 2. terlihat bahwa pada jam ke-0 pascaoperasi $\quad 52,4 \% \quad(n=22) \quad$ subjek tidak merasakan nyeri tenggorok setelah tindakan pemasangan LMA yang dilubrikasi dengan VCO. Hal ini menunjukkan bahwa lubrikasi VCO pada LMA menyebabkan permukaan belakang LMA menjadi lebih licin sehingga mampu mengurangi trauma pada mukosa laring pada saat pemasangan LMA dan dapat menghilangkan nyeri tenggorok pada sebagian besar subjek penelitian. Sebanyak 47,6\% (n=20) merasakan nyeri tenggorok pada jam ke-0 pascaoperasi. Pada jam ke-2 pascaoperasi prevalensi nyeri tenggorok berkurang menjadi $23,8 \%(n=10)$. Pada jam ke-24 pascaoperasi prevalensi nyeri tenggorok turun menjadi $9,5 \%(n=4)$.

Beberapa penelitian yang sudah dilakukan di berbagai negara menunjukkan hasil nyeri tenggorok pascaoperasi akibat penggunaan LMA sangat bervariasi. Hasil yang bervariasi ini dipengaruhi oleh jenis dan ukuran LMA yang digunakan, teknik insersi LMA yang beragam, keterampilan operator pada saat memasang LMA, perbedaan pada tekanan kaf LMA, ada atau tidaknya lubrikan yang digunakan pada saat pemasangan LMA, lama operasi serta jenis operasi yang dilakukan, dan lamanya pengamatan nyeri tenggorok pascaoperasi. Masalah yang sering kali terjadi pada saat pemasangan LMA pada pasien tanpa kelainan anatomi jalan napas adalah kegagalan untuk mencapai posisi LMA yang benar di hipofaring. Posisi yang ideal dari LMA adalah bila epiglotis dan esofagus berada di luar LMA dan pintu laring berada seluruhnya di dalam LMA.
Sehingga keberhasilan pemasangan juga dapat mempengaruhi kejadian nyeri 6,18,20,19,21-25

Pada jam ke-0 pascaoperasi penelitian ini mendapatkan hasil prevalensi nyeri tenggorok pascaoperasi sebesar 47,6\%, Gong et al. mendapatkan hasil sebesar 48,5\%, dengan menggunakan LMA tanpa lubrikasi. ${ }^{19}$ Kiran et al. mendapatkan hasil $0 \%$ dengan menggunakan LMA yang dilubrikasi dengan betametason gel 0,05\% dan 53,3\% dengan LMA yang dilubrikasi dengan jeli lignokain $2 \% .{ }^{25}$ Hasil penelitian ini lebih baik dibandingkan dua penelitian di atas, tetapi tidak lebih baik bila dibandingkan dengan lubrikan betametason gel 0,05\%.

Nyeri tenggorok pascaoperasi pada jam ke-2 tidak bisa dibandingkan dengan penelitian lain, karena tidak ada penelitian lain yang mengamati pada jam yang sama. Pada penelitian ini nyeri tenggorok pascaoperasi berkurang menjadi 23,8\%. Hal ini menunjukkan bahwa efek VCO sebagai analgetik dan antiinflamasi mulai bekerja. Penelitian Intahphuak et al. juga menyatakan bahwa VCO mulai bekerja sebagai analgetik dan anti inflamasi pada menit ke $60 .{ }^{11}$

Nyeri tenggorok pascaoperasi pada jam ke-24 diamati pada banyak penelitian, diantaranya Dingley et al. mendapatkan prevalensi nyeri tenggorok pascaoperasi sebesar $28,5 \%, 20$ Gong et al. sebesar 37,8\%,19 Venugopal et al. sebesar 23,5\%, ${ }^{22}$ Helmite et al. sebesar 23,9\%, ${ }^{24}$ Purba et al. sebesar $22,6 \% .^{23}$ Penelitian di atas dilakukan dengan menggunakan LMA yang tidak diberi lubrikasi, sehingga terlihat bahwa prevalensi nyeri tenggorok lebih tinggi dibandingkan dengan hasil yang diperoleh dari penelitian ini. Penelitian yang menggunakan LMA dengan lubrikasi dilakukan oleh Kiran et al. yang mendapatkan prevalensi nyeri tenggorok pascaoperasi sebesar 0\% pada kelompok LMA yang dilubrikasi dengan betametason gel 0,05\% dan $20 \%$ pada kelompok LMA yang dilubrikasi dengan jeli lignokain $2 \% .^{25}$ Gilani et al. mendapatkan prevalensi $35 \%$ pada kelompok LMA yang dilubrikasi dengan lidokain gel, dan 33,3\% pada kelompok LMA yang dilubrikasi dengan $\mathrm{NaCl}$ 0,9\%. Tidak didapatkan perbedaan bermakna secara statistik pada penggunaan kedua lubrikan tersebut.18 Patil et al. mendapatkan prevalensi nyeri tenggorok pascaoperasi sebesar $0 \%$ pada kelompok LMA yang dilubrikasi dengan betametason gel $0,05 \%$ dan $16 \%$ pada kelompok 
LMA yang dilubrikasi dengan jeli lignokain 2\%. Dibandingkan dengan penelitian di atas baik pada kelompok yang menggunakan LMA tanpa lubrikasi, maupun pada kelompok yang menggunakan LMA dengan lubrikasi maka prevalensi nyeri tenggorok yang didapatkan pada penelitian ini lebih rendah, yaitu sebesar 9,5\%.

Tidak ada pengobatan atau prosedur khusus yang sepenuhnya berguna untuk mengendalikan rasa nyeri tenggorok pascaoperasi. Penggunaan lubrikan pada saat insersi LMA sudah pernah diteliti, diantaranya betametason gel $0,05 \%$, jeli lignokain $2 \%$, xylocaine $10 \%$ spray, silko spray, endos gel, $\mathrm{NaCl}$ 0,9\%.6,7,9 Jika dibandingkan dengan penelitian yang menggunakan lubrikan pada saat pemasangan LMA, maka prevalensi nyeri tenggorok pada penelitian ini lebih rendah bila dibandingkan dengan beberapa penelitian yang pernah dilakukan. Pemberian VCO sebagai lubrikan pada LMA dapat mengurangi prevalensi nyeri tenggorok pasca operasi, tetapi efek VCO ini masih kalah bila dibandingkan dengan betametason gel $0,05 \%$.

Sampai saat ini belum ada penelitian yang dilakukan di Indonesia yang menggunakan LMA dengan lubrikasi, sehingga penelitian ini tidak bisa dibandingkan dengan penelitian yang ada di Indonesia. Demikian juga dengan VCO, belum ada penelitian yang sama yang menggunakan VCO sebagai lubrikan pada saat insersi LMA.

Berdasarkan beberapa penelitian di atas dan penelitian yang dilakukan saat ini, dapat disimpulkan bahwa penggunaan lubrikan pada LMA dapat mengurangi nyeri tenggorok pascaoperasi. Penggunaan VCO sebagai lubrikan pada penelitian ini dapat menurunkan nyeri tenggorok pascaoperasi.

Pada Tabel 3. dapat dilihat sebaran nilai VAS subjek penelitian yang mengalami nyeri tenggorok pascaoperasi setelah pemberian lubrikasi VCO pada LMA. Pada jam ke-0 pascaoperasi, $47,6 \%$ $(n=20)$ subjek penelitian merasakan nyeri dengan nilai VAS antara 1 - 3. Pada jam ke-2 pascaoperasi, subjek yang mengalami nyeri tenggorok berkurang menjadi $23,8 \%(n=10)$ subjek dengan nilai VAS yang juga menurun antara $1-2$. Pada jam ke-24 hanya 9,5\% (n=4) subjek yang mengalami nyeri tenggorok dengan nilai VAS 1. Nilai VAS 1 - 2 dikategorikan sebagai nyeri ringan, sedangkan nilai VAS 3 - 5 dikategorikan sebagai nyeri sedang. Terdapat 2 subjek yang mengalami nyeri tenggorok pascaoperasi dengan nilai VAS 3, hal ini bisa disebabkan karena kedua subjek tersebut menjalani operasi lebih dari 2 jam dan usia di atas 50 tahun dan berjenis kelamin perempuan.

Semua subjek penelitian yang masih merasakan nyeri tenggorok pada jam ke-24 pascaoperasi ini adalah subjek berjenis kelamin perempuan, usia lebih 50 tahun dan menjalani operasi dengan durasi lebih dari 120 menit. Beberapa penelitian menyebutkan jenis kelamin perempuan mempunyai mukosa yang lebih tipis sehingga mudah terjadi edema dan mengalami penyembuhan nyeri tenggorok pascaoperasi yang lebih lama dibandingkan dengan laki-laki. Selain itu semakin bertambah umur maka semakin meningkatkan kemungkinan adanya kelainan atau penurunan fungsi organ tubuh dan adanya penyakit penyerta. ${ }^{4}$ Penelitian yang dilakukan oleh Jaensson et al. juga menyatakan bahwa perempuan lebih sering mengalami nyeri tenggorok pascaoperasi akibat pemasangan LMA karena ada perbedaan anatomi faring antara lakilaki dan perempuan, dan kemungkinan bahwa LMA yang digunakan saat ini dirancang agar lebih sesuai dengan fitur anatomi faring laki-laki daripada perempuan dan oleh karena itu insiden nyeri tenggorok lebih rendah pada laki-laki. Pada 72 jam pascaoperasi, keluhan nyeri tenggorok pascaoperasi masih didapatkan sekitar $10 \%$ pada perempuan dan sekitar 3\% pada laki-laki. 26

Hasil penelitian yang dilakukan oleh Gong et al., yang menilai nyeri tenggorok pascaoperasi dengan VAS. Pada jam ke-1 derajat VAS berkisar antara $0-4$, pada jam ke-24 derajat VAS berkisar antara $0-3$, dan pada jam ke-48 derajat nyeri tenggorok pascaoperasi berkisar antara $0-1.19$ Helmite et al. melakukan penelitian dengan membandingkan nyeri tenggorok pascaoperasi pada tiga macam LMA yaitu LMA Supreme, LMA Unique, LMA i-gel. Intensitas nyeri diukur dengan VAS. Pada jam ke-24 pascaoperasi, nyeri ringan terdapat pada $14,2 \%-26,3 \%$ subjek, nyeri sedang pada $1,3 \%-5,4 \%$ subjek, dan nyeri berat pada $0,7 \%-1,4 \%$ subjek. ${ }^{21}$ Kedua peneliti ini tidak menggunakan lubrikan pada LMA untuk mengurangi nyeri tenggorok pascaoperasi. Gilani et al mendapatkan nilai VAS antara $4-7$ walaupun sudah LMA yang digunakan sudah dilubrikasi dengan lidokain, normal salin, atau 
pasien berkumur sebelum dilakukan pemasangan LMA. 18

Nyeri tenggorok yang dirasakan subjek semakin berkurang dengan berjalannya waktu. Bila dibandingkan dengan kedua penelitian di atas, penelitian yang dilakukan saat ini mendapatkan hasil nilai VAS yang lebih rendah pada jam ke-24 pascaoperasi. Intensitas nyeri tenggorok pascaoperasi yang dirasakan semua subjek pada penelitian ini pada jam ke-24 hanya kategori nyeri ringan. Lubrikasi LMA dengan VCO dapat menurunkan intensitas nyeri tenggorok pascaoperasi.

Pada tabel 4. dapat dilihat bahwa sebagian besar derajat nyeri berdasarkan NRS pada jam ke0 pascaoperasi adalah 1 sebanyak 47,6\% $(n=20)$ subjek. Pada jam ke-2 nyeri tenggorok dialami oleh $23,8 \% \quad(n=10)$ subjek dengan nilai NRS 1 (derajat nyeri tenggorok ringan). Sedangkan pada jam ke-24 nilai NRS 1 terdapat pada 9,5\% $(n=4)$ subjek penelitian. Hasil penelitian ini lebih baik dibandingkan dengan penelitian yang dilakukan oleh Gilani et al. dan Helmite et al. yang mendapatkan nyeri tenggorok pascaoperasi dengan derajat sedang. ${ }^{18,21}$

Subjek yang masih merasakan nyeri tenggorok pada jam ke-24 pascaoperasi adalah pasien dengan lama operasi lebih dari 120 menit. Hal ini sesuai dengan penelitian Waruingi et al. tahun 2015 yang menyatakan bahwa operasi yang lebih lama dapat meningkatkan prevalensi nyeri tenggorok. ${ }^{27}$ Gilani et al. juga mendapatkan hubungan yang bermakna antara lama operasi dengan dengan nyeri tenggorok. ${ }^{18}$

Berdasarkan hasil yang didapatkan pada penelitian ini dan dibandingkan dengan penelitian lain yang sejenis, maka lubrikasi LMA dengan VCO dapat menurunkan prevalensi nyeri tenggorok pascaoperasi. Penelitian ini berhasil membuktikan bahwa VCO berpotensi sebagai analgetik dan antiinflamasi yang dapat mengurangi nyeri tenggorok pascaoperasi akibat pemasangan LMA. Pada penelitian ini penggunaan VCO sebagai lubrikan lebih baik hasilnya bila dibandingkan dengan lubrikan lain seperti jeli lignokain, $\mathrm{NaCl}$ $0,9 \%$, dan gel lidokain.

Walaupun demikian, masih terdapat beberapa kelemahan dalam penelitian ini diantaranya jumlah sampel yang terbatas, dokter anestesi bisa saja menggunakan teknik insersi LMA yang berbeda, lama waktu pengamatan nyeri tenggorokan pascaoperasi hanya sampai jam ke24 pascaoperasi, sehingga tidak dapat diketahui dengan pasti kapan nyeri tenggorok pascaoperasi akibat pemasangan LMA sudah tidak dirasakan pasien lagi. Selain itu penelitian ini merupakan penelitian deskriptif untuk mendapatkan data prevalensi nyeri tenggorok pascaoperasi. Diperlukan penelitian lanjutan dengan jumlah sampel yang lebih besar dan metode acak tersamar ganda untuk melihat keunggulan lubrikasi VCO pada pemasangan LMA untuk mengurangi nyeri tenggorok pascaoperasi.

\section{Simpulan}

Prevalensi nyeri tenggorok pascaoperasi dengan pemberian lubrikasi VCO pada pemasangan LMA yang diamati mulai jam ke-0 pascaoperasi menunjukkan angka yang semakin berkurang pada jam ke-2, sehingga pada jam ke24 pascaoperasi hanya empat subjek yang masih merasakan nyeri tenggorok.

Derajat nyeri tenggorok pascaoperasi dengan pemberian lubrikasi VCO pada pemasangan LMA yang dinilai dengan skala NRS hanya ditemukan derajat ringan (skala NRS 1) dan tidak ada pasien yang mengalami nyeri tenggorok derajat sedang dan berat berdasarkan NRS.

\section{Ucapan Terima Kasih}

Terima kasih penulis sampaikan kepada semua pihak yang sudah terlibat dan memberikan kontribusi terhadap penelitian ini.

\section{Daftar Pustaka}

1. El-Boghdadly K, Bailey CR, Wiles MD. Postoperative sore throat: A systematic review. Anesthesia. 2016;71(6):706-17.

2. Williams LA. Laryngeal Mask Airway: a postoperative sore throat clinical practice guideline (dissertation). University of Southern Mississipi; 2018

3. McHardy FE, Chung F. Postoperative sore throat: cause, prevention, and treatment. Anesthesia. 1999;54:444-53.

4. Harijanto E, Firdaus R, Kurnia D. Perbandingan efektivitas tablet hisap amylmetacresol-dibenal dengan profilaksis deksametason intravena sebelum pemasangan pipa endotrakeal untuk mengurangi kekerapan nyeri tenggorok pascaoperasi. Anesthesia \& Critical Care. 2016;34(2),85-92.

5. Breivik H, Borchgrevink PC, Allen SM, Rosseland LA, Romundstad L, Hals EK, et al. Assessment of pain. British Journal Anaesthesia. 2008;101:17-24.

6. Patil BO, Sonavdekar SR, Mathur R. A relative study on laryngeal mask lubrication with $0,05 \%$ beclomethasone cream v/a 2\% lidocaine. Int J Med Res Prof. 2019;5(3):206-9. 
7. De Villager J, Soetens M, Van der Donck A. Sore throat with the laryngeal mask: does the lubricant matter? Acta Anaesthesiol Belg. 1996;47(4):195-8.

8. Keller C, Sparr HJ, Brimacombe JR. Laryngeal mask lubrication. A comparative study of saline versus $2 \%$ lignocaine gel with cuff pressure control. Anaeshesia.1997;52(6):592-7.

9. Tanaka Y, Nakayama T, Nashimori M, Sato Y, Furuya H. Lidocaine for preventing postoperative sore throat. Cochrane Database Syst Rev. 2009;8(3):CD004081.

10. Prabawati S. Minyak kelapa murni : Harapan nilai tambah yang menjanjikan. Balai Besar Penelitian Pasca Panen Institut Pertanian Bogor. Diunduh dari http://www.pustaka-

deptan.go.id/publikasi/wr272015pdf. Diakses tanggal 2 Oktober 2019.

11. Intahphuak $\mathrm{S}$, Khonsung $\mathrm{P}$, \& Panthong A. Antiinflammatory, analgesic, and antipyretic activities of Virgin Coconut Oil. Pharmaceutical Biology. 2010;48(2): 151- 7.

12. Sadeghi S, Wallace FA, Calder PC. Dietary lipids modify the cytokine response to bacterial lipopolysaccharide in mice. Immunology.1999; 96:404-10.

13. Ribeiro D, Freitas M, Tomé SM, Silva AM, Laufer S, Lima JL, et al. Flavonoids inhibit COX-1 and COX-2 enzymes and cytokine/chemokine production in human whole blood. J of Inflam. 2005;38(2). 858-70.

14. Bergsson G, Steingrímsson Ó, Thormar H. Bactericidal effects of fatty acids and monoglycerides on Helicobacter pylori. Int J Antimicrob Agents. 2002;20: 258-62.

15. Varma SR, Sivaprakasam TO, Arumugam I, Dilip N, Raqhuraman $\mathrm{M}$, Pavan $\mathrm{KB}$, et al. In vitro antiinflammatory and skin protective properties of virgin coconut oil. J Tradit Complement Med. 2019;20:5-14.

16. Setiani D. Efektifitas massage dengan Virgin Coconut Oil terhadap pencegahan luka tekan di Intensive Care Unit. Jurnal Husada Mahakam. 2014; 3(8):389-442.

17. Harahap YS,Tavianto D, Surahman E. Perbandingan angka keberhasilan pemasangan Laryngeal Mask Airway (LMA) jenis klasik pada usaha pertama antara teknik balon dikempiskan dan dikembangkan sebagian pada pasien dewasa. JAP.2016;4(1):30-5.

18. Gilani MT, Soleimania IM, Razavia M, Salehi M. Reducing sore throat following laryngeal mask airway insertion: comparing lidocaine gel, saline, and washing mouth with the control group. Rev Bras Anestesiol. 2015;65(6):450-4.

19. Gong Y, Xu X, Wang J, Che L, Wang W, Yi J. Laryngeal mask airway reduces the incidence of postoperative sore throat after thyroid surgery compared with the endotracheal tube: a single-blinded randomized controlled trial. BMC Anesthesiology. 2020;20(16):17.

20. Dingley J, Whitehead MJ, Wareham K. A comparative study of the incidence of sore throat with the laryngeal mask airway. Anesthesia. 1994;49:251-4.

21. Hermite LJ, Elisabeth D, Sophie B, Laure-Hélène $B$, Philippe C, Jean-Emmanuel. Sore throat following three adult supraglottic airway devices. A randomized controlled trial. Eur. J. Anaesthesiol. 2017;34(7):417-24.

22. Venugopal A, Jacob RM, Koshy RC. A randomized control study comparing the pharyngolaryngeal morbidity of laryngeal mask airway versus endotracheal tube. Anesth. Essay Res.2016;10(2):189-94.

23. Purba BA, Mafiana R, Puspita Y. Perbandingan teknik insersi Triple Airway Maneuver dengan teknik laringoskopi terhadap keberhasilan insersi dan profil hemodinamik pemasangan Laryngeal Mask Airway(LMA) klasik pada operasi elektif. J.Anest.Indon.2019;2(2):58-71.

24. Lin GJW, Lim YC, Wang J, Sahla S. An audit of postoperative sore throat using different laryngeal mask airways. Indian J.of Anaest. 2020;64(6):513-6.

25. Kiran S, Goel M, Singhal P, Gupta N, Bhardwaj M. Postoperative sore throat with $0.05 \%$ betamethasone gel and $2 \%$ lignocaine jelly used as a lubricant for ProSeal LMA (PLMA) insertion. Egypt.J.of Anest.2010;28(2):139-142

26. Jaensson M, Gupta A, Nillson U. Gender differences in sore throat and hoarseness following endotracheal tube or laryngeal mask airway: a prospective study. BMC Anesthesiol. 2014; 14(56):2-8.

27. Waruingi D, Mung'ayi V, Gisore E, Wanyonyi S. A randomised controlled trial of the effect of laryngeal mask airway manometry on postoperative sore throat in spontaneously breathing adult patients presenting for surgery at a university teaching hospital. Afr,Health Sci. 2019;19(1):1705-15. 